\title{
The Effect of Entrepreneurial Orientation on the Management Capability and Sustainable Innovation (Study on Batik Small and Medium Enterprises in East Java Indonesia)
}

\author{
Tri Murni, Taher Alhansji, M. Syafi'ie Idrus, Zainul Arifin \\ ${ }^{1}$ College of Administrative Sciences Malang. Indonesia \\ ${ }^{I}$ Faculty of Administrative Sciences Brawijaya University. Indonesia \\ ${ }^{I}$ Faculty of Economics and Business Brawijaya University. Indonesia \\ ${ }^{I}$ Faculty of Administrative Sciences Brawijaya University. Indonesia
}

\begin{abstract}
This study aims to examine and explain the effect of entrepreneurial orientation on the ability of management and continuous innovation in SMEs batik in East Java province of Indonesia. The findings of the study noted that Entrepreneurial orientation have a significant effect on the management capability but no significant effect on sustainable innovation. Management capabilities have a significant effect on continuous innovation. The study's findings also confirmed that entrepeneurial orientation will affect the sustainable innovation that has the support of management capabilities. In order to perform sustainable innovation, batik SMEs have the opportunity to develop a differentiation strategy. Innovation comes from creativity which is a collection of ideas, knowledge, skills and human experience. Innovation is also required to identify customer needs and develop new solutions to meet customer needs in the future. In order to perform sustainable innovation, batik SMEs have the opportunity to develop a differentiation strategy. Innovation comes from creativity which is a collection of ideas, knowledge, skills and human experience. Innovation is also required to identify customer needs and develop new solutions to meet customer needs in the future.
\end{abstract}

Keywords: Entrepreneurial Orientation, Sustainable Innovation, Management Capabilities, SMEs

\section{Introduction}

Entrepreneurial success is highly dependent on the role of entrepreneurship as a major actor in the running of business (Shane \& Venkataraman, 2000). Entrepreneurial orientation is an important factor in sustainable innovation. To achieve sustainable innovation companies need managerial capabilities in order to use resources effectively. Entrepreneurs with a strong entrepreneurial spirit and supported by management capabilities are needed in allocating the resources of the company in order to obtain an effective and efficient outcomes (Tidd et al, 1998).

Every business requires the application of management principles. The involvement of the business owner becomes an important aspect for the success of the business in the future. Pearce \& Robinson (2009) stated that the survival and growth of a company depends on the entrepreneur's ability to understand and manage their businesses. it means the ability of management is an important variable in the success of the business.

This research is based on the resource-based view or RBV synergized with market-based view and knowledge-based reasoning. According to the Resource Base perspective, its performance is determined by resource companies. Resource companies should be valued, rare, not easily to imitate and can not be replaced (Barney, 1991). Market-Based View focuses on the position of the company on market conditions and the competitive environment (Porter, 1990). Davenport (1999) revealed that knowledge management to support the innovation, creation of new ideas and utilization of organizational knowledge.

This study examines the RBV approach proposed by Barney (2002), Christensen (2005) and Pearce \& Robinson (2009) which suggests that the performance of the organization is essentially determined by the internal resources, especially those related to intangible assets such as entrepreneurial orientation, managerial capabilities and innovation. The purpose of this study is to examine and analyze the effect of entrepreneurial orientation on sustainable innovation with the management capability as an intervening variable.

\section{Theoritical Framework}

Relationship between Orientation Entrepreneurship on Management Capabilities and Sustainable Innovation.

Entrepreneurship and entrepreneurial orientation is different. Lumpkin (1996) provide a clear distinction between entrepreneurial orientation with entrepreneurial. Entrepreneurial orientation is the process of making decisions and activities that encourage entrepreneurship (Lumpkin, 1996). So entrepreneurship is a 
product of entrepreneurial orientation. The literature describes the orientation of the entrepreneur entrepreneurial personality (Littunen, 2000; Lee and Tsang, 2001; Olson, 2000). Hisrich, Peters and Shepherd (2005) stated that entrepreneurial orientation as an entrepreneurial feelings.

Management capabilities in understanding and managing the business will determine the growth and survival of the company (Pearce \& Robinson, 2009). SME owners who have the entrepreneurial spirit and supported by management capabilities are needed to coordinate the resources of the company in order to obtain an effective and efficient outcomes (Tidd et al, 1998).

The survival of the company is also highly dependent on the ability entreprenuer to survive and leading in competition. In a world that is changing faster, creativity and innovation are essential to the success and sustainability of the company. Creativity and innovation are determinant for small entrepreneurial businesses (Zimmerer et al, 2008). Knight (2000) explains that entrepreneurial orientation related to the search opportunity, the courage to take risks and the decision to act on the head of the organization. Orientation Entrepreneurship is a corporate value system and will determine the company's strategy. Companies that have a value system will continue to look for opportunities to try to penetrate new markets in order to take the opportunity to improve the company performance.

$\mathrm{H}_{1}$ : Entrepreneurship orientation has significant influence on the management capability

$\mathrm{H}_{2}$ : Entrepreneurial orientation has a significant influence on sustainable innovation

\section{Relationship between Management Capabilities and Sustainable Innovation}

The role of leadership to understand and perform the functions of management will determine the success of the business (Latif, 2002). According to Nuthall (2001), the managerial capabilities required in formulating business strategies used to achieve the goals that have been classified. The management capabilities include the ability to plan, define and evaluate the strategy (Ansoff, 1990)._Integrated plan is needed for the company to help the company allocate resources optimally.

The Ability of management to understand the business conditions in the future as economic conditions, the level of competition and changing consumer tastes is a means to achieve success. Swink (1999) states that the dynamics of the market have shortened product cycles, so companies must develop products on an ongoing basis. Any changes must be coupled with innovation to increase sales volume Tidd \& Pavitt (1998) stated that the management capabilities are essential in the process of product development.

Management capability is a set of skills and competencies both administratively and operationally in performing management functions to achieve organizational goals. Peters \& Lindsay (1998) said that during the growth phase, managers need to develop business management skills. Management expertise is used to manage the activities of marketing, production, finance and human resources. Edward (1994) stated that the degree of entrepreneurial management capabilities associated with functional ability in formulating policies to define strategic actions.

$\mathrm{H}_{3}$ : Management Capability has significant effect on sustainable innovation

\section{Method}

The samples were Batik Small and Medium Enterprises in East Java Indonesia. A total of 153 companies selected as the research object. Data were collected using a questionnaire consisting of 16 items with a rating scale questions 1 through 5. The data were processed using the Partial Least Square approach (PLS) with smartPLS software. Validity and reliability of research instruments shown in Figure 1 below.

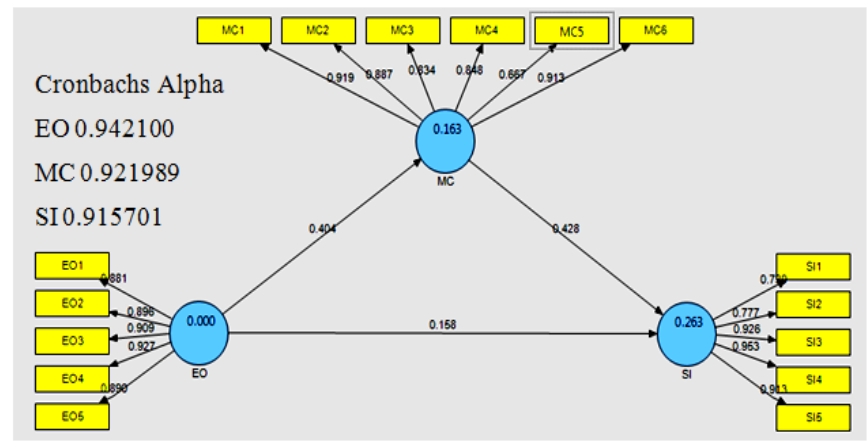

Outer loading of each construct more than 0.7 so that it can be said research indicators have a good degree of validity. Research instrument reliability test on all constructs have a Cronbach alpha value of more than 0.7 so that the research instrument has a good level of reliability. 


\section{Result}

There is a significant influence on the orientation of Enterprise Management Capabilities $\left(\mathrm{t}_{\text {stat }} 6.868>\mathrm{t}\right.$ table 1.976) with a path coefficient is 0.404 . Thus it can be argued that the hypothesis 1 which states that the orientation Entrepreneurship significant effect on the ability of management acceptable. There was no significant effect of orientation on the Enterprise Sustainable Innovation $\left(t_{\text {stat }} 1,289<t_{\text {table }}\right.$ 1.976). Thus hypothesis 2 is rejected.

There is a significant influence on the management capability of continuous innovation $\left(\mathrm{t}_{\mathrm{stat}} 5.372>\right.$ $\mathrm{t}_{\text {table }}$ 1.976) with a path coefficient is 0.428 . Thus hypothesis 3 is accepted. Test research hypotheses using PLS approach shown in Figure 2 below.

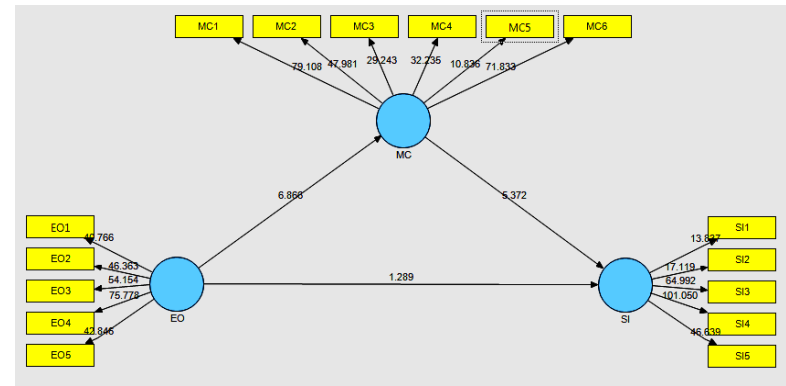

\section{Conclusion and Discussion}

\section{The effect of Entreprenurship Orientation on Management Capability}

The findings of this study support the RBV theory proposed by Pearce and Robinson (2009), which states that the RBV emerged as a strategy to develop core competencies. The core competencies include tangible assets, intangible assets and organizational capabilities. Furthermore, Pearce II and Robinson (2007) stated that the new company and a small business entrepreneur must be able to manage the three key elements to the process of entrepreneurship covering opportunities, entrepreneurship team and resource. Thus entrepreneurs are not sufficiently oriented entrepreneurship but also must have the management capabilities and solid business knowledge.

Tidd et al (1998) found that SME owners have a vision of entrepreneurial and management skills are needed to coordinate the resources of the company in order to obtain an effective and efficient results.

The findings of this study are also in line with the results of research conducted by Baum (2001) who found that the dimensions of the entrepreneurial nature has a direct positive effect on the implementation of competitive strategies. Further, the results of this study also support the results of research conducted by the Suci (2009) which states that the entrepreneurial orientation has positive significant effect on the management capability and business strategy on SMEs. The findings prove that to achieve high performance an entrepreneur must have the management capability.

\section{The effect of Entreprenurship Orientation on Sustainable Innovation}

The study findings suggest that the effect is not significant Entrepreneurship Orientation on Sustainable Innovation. Dimensions of innovative, proactive, willing to take risks, competitive and autonomy can not be used directly to improve the sustainable innovation. Although business owners have the attitude or high entrepreneurial spirit, but in running their businesses faced with many resource constraints. Although business owners have a strong entrepreneurial spirit, sometimes they also face resource constraints. For example, the limitations of marketing media. Direct marketing still dominates in the transaction. Advances in information technology such as the Internet and online business is still not used intensively. Business networks has not been explored extensively.

Schumpeter (1984), Knight (2000) and Omrell (1995) stated that entrepreneurial orientation is an effort for someone to accept the risks of innovation and change. Entrepreneurship is a characteristic of a person who loves business development in the future. Innovation on the other hand not only built a strong entrepreneurial orientation. Innovation requires special capabilities include conceptual skills, human skills and technical skill. Furthermore Tidd \& Pavitt (1998) stated that the management capabilities are essential in the process of developing a good product or service to SMEs nor large industries that require management planned to coordinate the company's resources.

There are differences in the results of this study with Ireland and Webb (2007), which states that entrepreneurial orientation has a direct effect on product innovation and process innovation. Another study conducted on SMEs in Iran by Madhoushi \& Hasim (2011) found that the orientation of Entrepreneurship has a significant positive effect on innovation performance. Knowledge management as a mediator to enhance the positive relationship between entrepreneurial orientation with the performance of inovation. 
This study found that entrepreneurial orientation has no direct influence on the sustainable innovation, but it needs to support management capabilities.

\section{The effect of management capability on sustainable innovation}

Management capability have a significant influence on Sustainable Innovation. This may imply that the ability to plan, set the vision, mission and objectives, coordinating employees, motivate employees, control of the working methods and decision-making required in the Sustainable innovation.

These findings agree with Jones (2004) which states that innovation is a process within the organization to utilize the skills and resources to develop new products or services or to build a new system of production and operations that address the needs of the customer. Innovation in the organization will be connected directly with organizational objectives, business plans and placement of a competitive market. According to Tidd \& Pavitt (1998), management capability is very important because the process of developing products or services to SMEs and large industries each require management activities to coordinate the resources of the company. Hamilton (2009) noted that the ability of innovation will be successful depends on the size of the resource and managerial competence of SMEs.

The findings of this study enriches the concept of management strategies that reflect the excellence of innovation proposed by Zadek (2004), Starik \&Sharma (2005) and Pearce \& Robinson (2009). Innovation in the company becoming an important issue, because a lot of companies that failed to survive in the modern industrial world is caused by a lack of innovation.

Sustainable innovation is described as part of the evolution to be executed by the company. In Batik Enterprises, innovation can be started from something that already exists, or from experience. Periodic market research is needed to explore creative ideas as a source of innovation.

The new finding that distinguishes this study with previous studies is not significant effect Entrepreneurship orientation towards continuous innovation. Based on the results of SEM analysis, it is known that the entrepreneurial orientation can not directly affect the sustainable innovation, but must be supported by a management capabilities.

\section{Reference}

[1]. Ansoff,I. 1990. The New Corporate Strategy, McGraw- Hill, New York

[2]. Barney ,J.B.1997, Gaining and Sustaining Competitive Advantage, Addison-Wesley Pub. Co, New York

[3]. Baum, J. Robert, 2001, A Multi-Dimensional Model of Venture Growth, In Press- Academy of Management Journal.

[4]. Christensen C.M, Raynor M.E, 2003, The Innovator's Solution, Creating and Sustaining Successful Growth, Harvard Business School Publishing Corporations.

[5]. Davenport, T,De Long, D (1999), Succesfull Knwledge Management Projects, The Knowledge Management, Yearbook, 1999 2000 .

[6]. Dess, Lumpkin and Covin, 1997, Entrepreneurial Strategy Making and Firm Performance: Test of Contingency and Configurational Models, Strategic Management Journal, Vol.18, No.9, pp. 677 - 695

[7]. Hisrich R.D, Petes \& M.P. Sheperd, 2005, Entrepreneurship, 6 ed. McGraw-Hill Boston

[8]. Ireland, R.D \& J.W. Webb, 2007. A Cross Disciplinary Exploration of Entrepreneurship Research. J.Manage, 33(6): pp 891 - 927.

[9]. Jones G.R, 2004, Organizational Theory, Design and Change, Prentice Hall.

[10]. Knight, Gary, 2000. Entrepreneurship \& Marketing Strategy: The SME Under Globalization, Journal of International Marketing, Vol. 8, No.2, 2000, pp. $12-32$

[11]. Latif, David.A, 2002. Model for Teaching the Management Skills Component of Managerial Effectiveness to Pharmacy Students, American Journal of Pharmaceutical Education, Vol. 66. Winter,2002, Winchester VA $22601-5195$

[12]. Lee D Y and Tsang E W K, 2001, The Effect of Entreprnuer Personality, Background and Network Activities on Venture Growth, Journal of Management Studies 38-4 pp 583-602

[13]. Lee Then Chye et.al, 2010, Are Managerial Competencies a Blessing to the Performance of Innovative SMEs in Malaysia ?, International Journal of Economics and Management 4 (I ) : 120 - 136 ( 2010 ).

[14]. Littunen, Hannu, 2001. Entrepreneurship and Characteristies of The EntrepreneurshipPersonality. International Journal of Entrepreneurial Behaviour and Research. Vol.6.No.6, 2000. pp. 295 - 309

[15]. Lumpkin GT and Dess G.G, 1996, Clarifying the Entreprenuerial Orientation Construct and Linking it to Performance, Academy Management Review, Vol.21 No. 1, pp135-172

[16]. Madhoushi, Mehrdad; Abdolrahim Sadati, Hamidreza Delavari, Mohsen Mehdivand and Ramin Mihandost. 2011. Entrepreneurial Orientation and Innovation Performance: The Mediating Role of Knowledge Management. Journal of Business Management 3 ( 4 ): 310 - 316, Published November 15, 2011.

[17]. Nuthall P.L, 2001, Managerial a Review of its basis and Potential Improvement using Psychological concepts, Agriculture Economics, Vol 24, pp 247-262

[18]. Olson D E, 2000, The Role of Entrepreneurial Personality Characteristic on Entry Decisions in Simulated Market, USASBE/SBIDA, pp1 - 13

[19]. Pearce \& Robinson, 2009, Strategic Management, Formulasi, Implementasi dan Pengendalian, Buku 1, Edisi 10, Penerbit Salemba Empat, Jakarta.

[20]. Pearce II JA and Robinson Jr R.B, 2007, Strategic Management Formulation, Implementation and Control, 10 ed McGraw-Hill, Singapore

[21]. Peter Balan and Noel Lindsay, 1998. Innovation Capability and Entrepreneurial Orientation Dimensions for Australian Hotels, Sustainable Tourism, Cooperative Research Centre.

[22]. Porter, M.E, 1990, The Competitive Advantage of Nations, Free Press, New York

[23]. Schumpeter,J.A, 1984. The Theory of Economic Development, Harvard University Press: Cambridge, MA, 
[24]. Shane, S \& Venkataraman, S. 2000. The Promise of entrepreneurship as a fild of research, Academic Management Review, Vol 25.

[25]. Starik, M, S.Sharma, et al. 2005. New Horizons in Research on Sustainable Organizations: Emerging Ideas, approaches and tools for practitioners and researchers,Sheffield, Greenleaf.

[26]. Suci, Rahayu Puji, 2009, Pengaruh Orientasi Kewirausahaan, Dinamika Lingkungan, Kemampuan Manajemen serta Strategi Bisnis terhadap Kinerja, Studi pada IKM Bordir di Jawa Timur, Penerbit Dian Prima Lestari, Anggota Ikapi Jawa Timur.

[27]. Suci, Rahayu Puji, 2009, Peningkatan Kinerja melalui Orientasi Kewirausahaan, Kemampuan Manajemen, dan Strategi Bisnis, Jurnal Manajemen dan Kewirausahaan, Vol. 11, No. 1, Maret 2009, 46-58

[28]. Swink, M.L. 1999, Threats to New Product Manufacturability and the Effects of Development Team Integration Processes, Journal of Operations Management, 17, pp: $691-709$.

[29]. Tidd, J, Bessant, J and Pavitt, K, 1998, Managing Innovation- Integrating Technological, Market and Organizational Change, John Wiley \& Sons, Chichester.

[30]. Zadek, S, 2004, “On Civil Governance”. Development 47 (3): pp 20 - 28.

[31]. Zimmerer, Thomas W and Scarborough, Norman M, 2008, Essentials of Entrepreneurship and Small Businees Management, Pearson Education, inc, New Jersey 